\title{
Alcoholic Beverage Server Liability and the Reduction of Alcohol-Related Problems: Evaluation of Dram Shop Laws
}


Technicel Report Documenration Poge

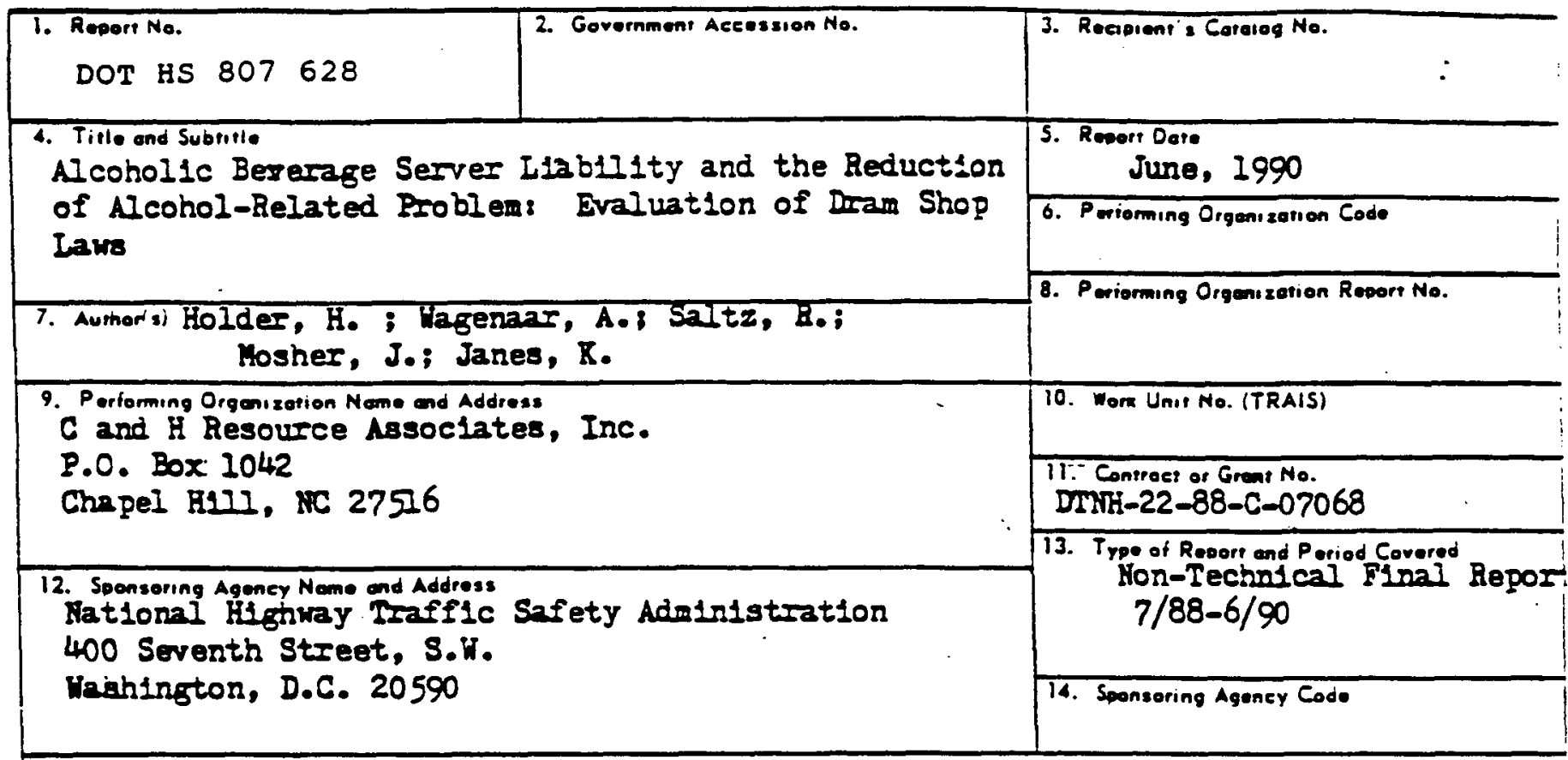

15. Suppiementary Notes

Ir. Rlchard Compton, Contracting Officer's Technical Bepresentative

16. Abstroct

The project was an evaluation of the potential for the legal liability of alcoholic beverage servers to stimulate preventative serving practices and thus reduce alcohol-involved traffic problems. Iegal analyses of judicial and legislative actions within individual states determined that states could be ranked according to their relative level of liability exposure. Utilizing both cross-sectional. and longitudinal designs, the project found that in states ranked highest in server liability there was more publicity about such liability, greater awareness and concern among iicensed establishment owner/managers, and differential serving practices compared to states with lowest liability exposure. A time series analysis in one state, Texas, which had experienced a dramatic change in server liability (from relatively little to relatively high) and significant accompanying publicity had a statistically significant drop in alcohol-involved traffic crashes as a result. The project concluded that server liability with incentives for preventative serving practices had more potential for reducing alcohol-involved traffic problems than strict liability alone.

17. Koy Words

Alcohol Beverage, Server Ilablilty,

Traffic Crashes, Highray Safety
18. Distriburlon Srorement

Document avaliable to the public through the National Technical Information Service, Springfield. TA

\begin{tabular}{|c|c|c|c|}
\hline $\begin{array}{l}\text { 19. Securry Clossit iof this redorn } \\
\text { Unclassifled }\end{array}$ & $\begin{array}{l}\text { 20. Socurnix Clossidioi this oogen } \\
\text { Unclassified }\end{array}$ & 21. No. $28^{\text {Poges }}$ & 22 Price \\
\hline
\end{tabular}




\section{Profect stake}

Harold D. Holder, Ph.D., Principal Investigator

Kathleen Janes, J.D.

James Yocher, J.D.

Robert Saltz, Ph.D.

Alexander C. wagenaar, Ph.D.

Toni S. Clifton, M.l.H., Project Administrator

Acknowledgements :

Steven Spurr, Ph.D., J.D., Wayne State University, conducted the legal and economic analysis of State Liability Insurance.

Robert Soloman, J.D., University of Western Ontario, Canada, worked with James Mosher on the analysis of restrictiors and limitations of server liability and wrote the review of Canadian Liability law in Chapter II.

William Luckey. Ph.D., University of North Carolina, completed most graphics in this report and graciously made his data set of North Carolina media coverage available to the project.

Mrs. Janet Jestor conducted the content analysis of State Trade Journals.

James Peters, Responsible Hospitality Institute, provided valuable consultation and technical support to the project.

Ms. Debra Headricks, University of North Carolina and later, Austin College, Texas, undertook a computer-based search of Texas newspapers and of newspapers in selected high and low liability states.

Mrs. Betty Frasca typed and organized the many versions of the final report.

The Prevention Research Center, Berkeley, CA, provided data on Texas traffic crashes from its historical files and made its files of dram shop liability cases and of laws and regulations on alcoholic beverage control available for use by this project. 


\section{PROJECT OVERVIEW}

\section{a. Introduction}

The goal of this project was to evaluate the contribution of alcoholic beverage server liability (dram shop liability) ${ }^{1}$ to preventative alcohol beverage serving practices and thus to reductions in alcohol-involved traffic problems. The basic empirical desiçn for this profect was both cross sectional and longitudinal.

The first phase was a legal analysis including legal data inventory and selection of Case study states, review of legislative anä case law history for these states, evaluation of tort reform, and review of liability insurance issues. The inventory consisted of the collection of extensive available data on dram shop liability law in the 51 united states jurisdictions.2 The dimensions along which state server liability laws differ were identifiei using a wide variety of secondary data sources. These data priduced a composite description of exposure to dram shop liability in each state. Next, an expert (Delphi) panel of dram shop legal experts rated these factors describing liability exposure in order to develop a score for each state in terms of overall liability exposure. Results were used to select a set of high and low liability and change case study states for furthar legal and empirical analysis.

Once case study states were selected, a review of their legislative and case law history was completed on each state. In addition, an legal assessment of recent tort reform proposals and actions was undertaken to determine implications for server liability in general. An important aspect of server liability is insurance to cover liability exposure. Reviews of insurance availability, costs, and other matters were conducted.

The second phase of the research program included cross-sectional analyses to examine relationships among dimensions of dram shop liability, publicity about such liability, server awareness, and serving practices. Using survey data collected by a major national trade journal and a professional trade association, differences in perceptions and actions by licensed establishments in high and low liability states were examined. In addition, a content analysis of

'Dram shop is used here in an historical sense. A dram was a unit of measure for serving alcohol in Colonial times, and thus establishments whicl: sold alcohol were called "dram shops". (Mosher, 1979d)

${ }^{2}$ Fify states plus the District of Columbia 
major newspapers and state trade journals in each of these states provided information about dram shop publicity. Two states with significant changes in server liability were used in a longitudinal design. In one state, Texas, a time-series quasi-experimental design was used to evaluate changes in aggregate alcohol-involved traffic crashes after major changes in dram shop liability and/or litigation occurred. Box-Jenkins time-series analyses of longitudinal crash data were used to test the hypothesized causal relationship between state dram shop characteristics and alcohol-involved crash levels.

A unigue advantage to the overall research design is that cross-sectionai and longitudinal analyses permitted

cross-validation, 1.e.., we were able to see whether an effect discovered in the cross-sectional analysis also appeared when looking at the impact of dram shop liability over time by research questions approved by the Natlonal Highway Traffic Safety

Administration, (letter, August 30, 1988).

There were 16 research questions which guided the project as shown below:

\section{REBEARCE QUESTIOX8}

1. What states have enacted dram shop liability laws or recognize common law dram shop claims?

2. What are the provisions and limitations of such laws?

3. Wich states have eliminated or restructured existing dram shop laws within the last 5 years?

4. What elements of statutory and common law contribute to a retaller's dram shop liability exposure?

5. What is tne distribution of dram shop liability by state?

6. What is the levell of report and publicity concerning dram shop litigation and cases within case study states?

7. What is known about dram shop liability insurance availability and coverage costs?

8. What are servers' perceptions of risk of dram shop litigation within a study state?

9. What 18 the relationship of dram shop liability and litigation to legislation which mandates or encourages server training?

10. What is the relationship of dram shop liability and litigation to server training? 
11. What is the relationship of dram shop liability and litigation to retall serving practices?

12. What kinds of server training programs are offered by states?

13. What are differences in server training between dram shop and non-dram shop states?

14. What is the effect on alcohol-involved trafsic crashes (if any) of a signiflcant change in dram shop liability exposure?

15. What are the potential effects of the four recommended tort reforms on dram shop liability and highway safety?

16. What are the factors which increase or decrease the preventive aspects of dram shop liability?

B. Brief summary of Dram shop Liability History

Dram shop llability refers to the civil liability faced by both commercial servers and social hosts for the injuries or damage caused by their intoxicated or underage patrons and guests. A typical dram shop liability scenario involves bar $A$, which serves obviously intoxicated or underage patron $B$. Patron $B$ leaves the establishment and, while intoxicated, crashes into citizen $C$ on $a$ public highway. Dram shop liability law permits, within certain guldelines, citizen $C$ to sue both bar $A$ and patron $B$ for losses associated with the crash.

Dram shop liability can be imposed on retailers by either state courts or state legislatures. Courts can create a cause of action, even without clear legislative direction, through interpretation of common law principles of negligence. Legislatures may enact legislation that imposes liability, which may or may not be based on principles of common law negligence. Legislatures have the power to modify common law, provided that the modifications do not violate due process or some other aspect of constitutional law.

Thus, the state legislature is the final arbiter regarding the nature and extent of dram shop liability law in a given state. In many states, there is both a court-based and legislative-based dram shop liability cause of action because the legislation does not clearly modify or supersede the common law action established in the state courts. Because of the concurrent powers of state legislatures and courts, the united states has a patchwork of dram shop laws, with each state having its own particular characteristics. This makes the study of the impact of dram shop law on traffic safety particularly difficult and challenging to the research community. 
The retall alcohol beverage industry has experienced dramatic changes in the last two decades, particularly regarding its role in preventing alcohol-related motor vehicle crashes. Until the early 1970s, policy makers and opinton leaders did not view commercial servers or social host:s as having any responsibility for the harm caused by their patrons or guests. Responsibility was placed solely on the drinker, and the server was viewed as playing a passive, largely irrelevant role. This lack of responsibility was reflected in the old common law rule of torts that a drinker's actions are the sole, proximate cause of any crash or damage. Consequently, the server was absolved of any legal responsibility. The old rule, which was recognized by virtually all state courts, applied even if the rotailer blatantly violated state alcohol laws prohibiting sales to obviously intoxicated or underage persons.

In this earlier period, which was adhered to by most state courts up to 1975 and even 1980, only a handful of legislatures had enacted dram shop statutes, many of those dating back to a preProhibition period. Ihese early statutes did impose liability on retailers for serving intoxicated or underage persons, or "habitual drunkards." Many of the provisions did not rest on common law interpretations of neçligence. In general, they were considered relics of an earlier era."

The citizen's movement: to prevent drinking-driving in the 1970 s dramaticaliy changed the legal landscape. Increasingly, state courts refused to accept the old common law rule, finding instead that retallers could be held liable for serving alcohol to obviously intoxicated or underage persons who subsequently injured others. This "new columon law rule" of third-party liability is based on general concepts of negligence law.

Under the new common law rule, both the drinker and the retailer are viewed as potential defendants in a dram shcp case (in legal terminology potential "tortfeasors"). The potential harm is clearly foreseeable, and the imposition of legal responsibility on the server is designed to protect those likely to be harmed. Since this liability is predicated on common law principles of negligence, the state courts had the power to adopt the new common law rule as part of their inherent powers without the need for legislative directives. Support for the new common law rule came

${ }^{3}$ For discussion, see J. Mosher, Dram shop law and the prevention of alcohol-related problems, Joumal of Alcohol Siudies 40 (9): 773-798/September 1979; J. Mosher et al Liquor Liability Law (Matthew-Bender Inc., NY(1987); G. Rinden, Proposed prohibition: erosion of the common law rule of non-liability for those who dispense alcoliol, 34 Drake L. Rev. 937 (1987). Dram shop laws, as with other areas of tor law, are applied primarity at the state level, with each state establishing its own set of rules and procedures. There are no federal laws which directly impact this state prerogative regarding dram shop liability. 
from many quarters -- legal scholars, policy advisory bodies, and cltizen's action groups. They viewed these llablitity principles as an integral part of the effort to provant alcohol-related traffic crashes as well as other alcohol-related problems".

'The Model Alcoholic Beverage Retail Licensee Liability Act of 1985, 12 Western State Law Review 442-517 (Spring 1985). Mosher, Colman, Roth and Janes were principal authors of the Model Act, which was funded by Grant \#R01AA0621-01 from the National Institute on Alcohol Abuse and Alcoholism. The Model Act project involved the analysis of every dram. shop stature and over 1,000 court opinions, key variables of which were analyzed with the aid of a specially designed computer program. This research experience and data base provided a sound basis for establishing the key variables for the present project. 


\section{SUMMAR Y A N D CONCLUSIONS}

\section{A. Introduction}

This non-technical report summarizes the overall conclusions from this project in throe parts. This chapter has three sections. The first summarizes specific findings. The second section summarizes a conceptual model which reflects the research findings of this project and relevant other research. The third section makes final conclusions and recommendations.

\section{B. Summary of specifle Findings}

significant findingis from the varlous research components of this project are shown bielow.

Ratings of Berver Ilability Ixpoeure for states-All known state cases and statutes relating to dram shop (server) liability were analyzed to identify those which influence the risk of such liability in any state. As a result of this legal analysis, 26 factors were identified and grouped into five categories: (1) acts giving rise to liability such as serving minors or intoxicated persons, (2) liability standards, such as negligence, recklessness or strict liability, (3) standing to sue, including the injured third party, injured adult drinker, or injured minor drinker, (4) legal restrictions isuch as limits or recovery caps upon suits, and (5) defenses available to a defendant, including responsible business practices and/or training of servers.

An expert (Delphi) panel of seven dram shop liability authorities was formed to rate the relative importance of each of the 26 factors in contributing to liability exposure or potential in any state. Each expert panel member assigned a relative weight or score to each factor within a defined range from plus 10 to minus 10. A positive score was judged to increase liability exposure and a negative score was judged to decrease exposure. These scores were then averaged across all raters for each factor. Through a series of ballots lollowed by discussion, a final set of weights were obtained.

The factors judged to be the most influential in increasing or decreasing licensee llability included liability for serving minors (8.4), liability for serving a person who becomes intoxicated (10), strict liability $(9.7)$, allowing an adult drinker to sue (8.6), allowing an innocent third party to sue $(9.0)$, limiting recovery to less than $\$ 100,000(-8.6)$, and statutory presumption of responsibility (-9.0). Statutory presumption of responsibility for licensees who participate in approved server training program was 
also judged as important.

The potential influence of a specific factor in practice is legally or judiclally uncertain. Where no legal precedent exists on a certain topic, the risk of a judicial finding against the plaintiff is greater than where a negative precedent or prohibitory statute exists. The expert panel sought to quantify the effect of uncertainty on the key factors by assigning half the weight of a positive factor.

The rating weight assigned to each specific factor reflected the elements considered by the expert panel. These weights do not take into account several other factors which might influence the severity of dram shop liability, including state court rules and procedures, general tort law rules, public opinion, and availability of liability insurance.

The server liability law and case precedents of all 51 U.S. jurisdictions (50 states plus District of Columbia) were coded as of mid-1988 according to the presence or absence of each of the 26 factors. By applying the assigned weights for each factor to the codes for each state and suming over all factors, a final llability score was developed for each state.

Table 1 shows each of the states and the District of Columbia ranked according to their final assigned score from highest to lowest liability.

Three states had summary scores over 60 . These states, Indiana, Pennsylvania, and South Carolina, allow dram shop liability based on common law case precedent. In contrast, the lowest rated states, Arkansas, Kansas, Nebraska, Nevada, South Dakota, Maryland and Virginia (all of which had scores less than 10), limit liability through case law precedent. Courts in these states have consistently refused to allow liability for service of alcohol in the absence of legislation establishing state policy.

States in which liability is defined by statute tended to fall in the middle range of scores. For example, North Carolina, Utah, Alaska, New Mexico and New York, all of which have statutes allowing liability with certain limitations, scored in the low 50s. States whose statutes severely limit dram shop liability, such as Florida and California, scored in the 40 s.

Final state scores were utilized to identify states for further case study. Four high liability states were selected: Indiana, Massachusetts, Pennsylvania, and South Carolina. Five low liability states were selected: Arkansas, Delaware, Kansas, Maryland, and Nevada. Effort was made to obtain some regional dispersion, though it was impossible to obtain representatives 
TARUR 1

STATB GWVE UABITIY RWK SCORES

VARY HIGH

Ieding

70.3

Pesnoptraita

South Caolina

HIGH

Miculaippi

Orinboen

Masenchuerts

New Jeney

Wrowing

Moatana

Ditrict of Columbla

Alabam.

Washington

Utah

North Caroline

Hownii

61.8

61.3

60.3

39.5

59.0

59.0

38.3

57.3

55.4

55.3

55.0

54.5

MEDIUM

Texas

Kentucky

New York

Alark

53.0

526

51.9

lowa

51.8

New Mecico

51.3

50.3

Ohio

48.8

Rbode isiand

LOW MEDIUM

Consecticul

Wear Vinginia

New Hampatire

46.7

North Ditola

46.4

45.4

Tenneacee

Forida

Wreconsin

Orezon

Ilinois

Califomia

Arizona

Minnesota

Vermont

44.4

44.2

43.5

43.4

43.2

42.5

41.8

41.3

Low

Louisians

Idaho

38.5

Michigan

38.5

Georia

36.2

Mineouri

Maine

32.8

Colondo

32.5

Deloware

28.4

17.7

VERY LOW

Arteanas

Kansas

Nebraska

Nevada

South Datkota

Maryland

Virginia

8.2
8.2
8.2
8.2
8.2
1.2
1.2
42.9

AVERACE 
from every region of the country.

In addition, two states, North Carolina and Texas, were selected as case study states which had undergone a significant change in server liability. These states were examined in a longitudinal analysis to determine the effect of the change in liability on alcohol involved traffic problems.

Legal Restriction on Dram 8hop Ilability statutes -- This study reviewed four types of legal restrictions that have been used to modify dram shop liability law in the United states: 1) stricter evidentiary standards (such as clear and convinging evidence); 2) stricter liability standards (such as recklessness or wantonness); 3 ) elimination of joint and several liability; and 4) limitations on recovery (damage caps). These restrictions represent a legislative reaction to the recent tendency of state courts to expand application of common law principles to negligent service of alcohol.

Evaluation of these restrictions was based on their potential impact on retailers' responsible business practices and on the

appropriateness of the restrictions within existing legal frameworks. Appropriateness was considered by evaluating 1) the fairness or equitable distribution of burden on plaintiffs and defendants, 2) consistency with related legal provisions such as alcohol control laws and 3) clearness of the legal provision to those affected by it.

The legal analysis concluded that all four types of restrictions reduce incentives for retailers to adhere to responsible service practices. Furthermore, the restrictions are inconsistent with related legal provisions, such as alcohol control laws and other tort law, and unfairly distribute the burden of liability on the victim. specific findings from this part of the project included:

- The five categories of law judged to be most related to server liability in any state were: (1) acts giving rise to liability, liability standards, (3) standing to sue, (4) legal restrictions, and (5) defenses.

- When specific legal factors were assigned relative weights and applied to the legislation and case law in each state an overall score of server liability exposure was obtained. These final scores were judged to be generally consistent and reliable by the expert panel.

--highest liability states based on these scores were judged to include Indiana, Pennsylvania, and south Carolina. Lowest liability states were judged to be Maryland and Virginia.

--Common law states (those with no existing statutes concerning server liability) tended to fall in the highest and lowest categories. states with dram shop liability statutes tended to have middle or moderate scores. This appears to be the result of a response in these states to court decisions concerning liability.

-Fear of open-ended liability defined under common law by court acts appears to stimulate legislation to establish boundaries for liability including setting limits on the amount of potential awards which might be made. 
Lagal ristories of case 8tudy 8tates -- Eleven case study states (5 low, $4 \mathrm{high,}$ and 2 change states) were chosen for closer study of their hospitality industries and traffic safety data. Representative etates of high or low liability were chosen for study based on their scores on the dram Bhop liability rating scale. States which had experienced a major change in dram shop liability climate in the last decade were also selected for study because they offer the opportunity to measure the effacts of the changes.

Five states were chosen from the low or very low groups of liability scores. Courts in these states have consistently refused to recognize dram shop liabliity in the absence of legislation which mandates such llability. Brief liggal histories of each follow:

Arkansas (8core=8.i2) courts have consistently refused to allow dram shop liablilty sincis the first case which raised the issue in 1965. In 1986 and 1987 cases involving 1llegal sales to minors, the court refused to reverse its earlier opinion in the absence of legislation allowing dram shop Llability.

In Delaware (8core:17.7) although a trial court had allowed a dram shop liability suit to proceed in 1978 (Taylor v. Ruiz), there was no binding legal precedent regarding dram shop liability in Delaware until 1981. In that year the supreme Court of Delaware ruled that violation of liguor control laws could not be used as the basis for a suit by an intoxicased person against a licensee. The court deferred to the state legislature to define state policy regarding dram shop liablilty. However, a 1988 negligence case against a social host (DiOssi $v$. Maroney) raised the possibility of liability for negligent service of alcohol with a holding that a property owner owes a duty to exercise reasonable care in providing a safe workplace, especially in light of the known risks of underage drinking.

In kansas (8core=8.2) the supreme court first adopted the common law rule of nonliability for a liquor vendor in 1949 (Stringer v. Calmes). In 1985 the court again refused to impose common law negligence liability on a licensee in the absence of legislation (Ling v. Jan's liquors). This decision was reaffirmed in 1986 with a holding that Kansas common ?aw does not recognize liability on the part of liquor vendors (Fudge $v$. City of Kansas City).

The Maryland (8cort $=1.2)$ supreme court adopted the common law rule that an innocent party has no cause of action against a liquor vendor in 1951 (State $v$. Hatfield). That decision was upheld in Felder $v$. Butler (1981). Fisher v. O'Connors (1982) and Kuykendall v. Top Notch Laminates (1987).

The revada (8corea.2) Supreme Court has refused to allow licensee liability without legislation which authorizes it. In 1969 and again In 1982 the court refused to allow a common law liability claim for selling alcoho.. to an intoxicated person, either on riegligence prisciples or negligence per se (Hamm v. Carson City; Nugget and Yascovitch $v$. Wasson).

Four states from the high and very high groups on the dram shop liability scale were chosen as case study states. These states all had scores over 60 and are from diverse areas of the country east of -r....... They are characterized by extensive common-iaw 
liability, oven where statutes limiting liability exist.

Indlare (800re $=70.3)$ has recognlzed common law actlons for negligence In serving alcchol since 1966 (Elder v. Fisher). In that case the Indlana supreme court held that the statute forbidding furnishing alcohol to a minor can be the basis of a suit against a licensee who violates 1t. This rationale was extended to social hosts as early as 1974 (Brattain $v$. Herron). In 1980 the right to a cause of action was extended to the intoxicated person (Parrett $v$. Lebamoff) although the defense of contributory negligence was allowed. A statute passed in 1988 (Ind. Code section 7.1-5-10-15.5) is intended to limit previous liability under common law by requiring that the server have "actial knowledge" that the patron is visibly intoxicated. However, if common law actions apart from the statute are allowed by the courts, the limitation of the new liability statute may not offer protection to Iicensees.

Massachusetts (8core=60.3) courts first recognized the potential for dram shop liability in 1967 (Adamian v. Three Sons). In that case the Supreme Judicial Court of Massachusetts held that violation of a criminal statute could be used as evidence of negligence, and that the statute was intended to safeguard the general public. A 1979 case extended the Adamian ruling to violation of statute prohibiting sales to minors (wiska v. Stanisiaus social club).

In Peansylvasia (8core=70.0) the present dram shop liability statute (47 PS 4-497), enacted in 1965, limits liability actions to third party suits in which the person served was visibly intoxicated. Thus, liability for serving minors would seem to be precluded. However, the Pennsylvania supreme court has been very willing to apply common law negligence principles beyond the provisions of the statute, including liability for serving minors and for injuries to intoxicated persons (Schelin v. Goldberg, 1985; Congini v. Portersville valve Co, 1983). The statutory immunity from third party liability suits did not protect the licensee-from common law negligence claims. Thus licensees in Pennsylvania are subject to both statutory liability for service to visibly intoxicated persons and common law liability for violation of the criminal statute banning sales to minors.

The Bouth Caro!.Ina (8core=65.0) Supreme court held in 1985 that violation of a statute prohibiting sale of alcohol to an intoxicated person could be the basis of a liability suit because the intoxicated person was among the class of people protected under the statute (Christiansen v. Campbell). In allowing the intoxicated person to sue licensees who serve them, south carolina law is extremely liberal.

Two states -- North Carolina and Texas, -- in which major changes in liability have occurred have been chosen as case study states to investigate the impact of these changes on alcohol involved traffic crashes. Selection criteria were a dramatic shift in liability exposure in the last seven years and availability of alcohol-involved motor vehicle crash data.

North carolina (8core=55.0) had not recognized dram shop liability prior to 1982 . In 1982 a federal appeals court interpreted North Carolina law to allow broad dram shop liability (Chastain v. Litton systems). This holding was affirmed by a North carolina appellate court in 1983 (Hutchens $v$. Hankins). These cases held that a 
defendant, even a non-licensee, could be sued for illegally furnishing alcohol to an 1ntoxicated person under common-law negligence principles. Subseguent appellate decisions held that off-premise ilcensees could face liability for eervice to minors (Freeman $v$. Finney) and that an intoxicated person's contributory negligence could be used as a defense (Brower v. Robert Chappell \& Associates). Another mafor change occurred in 1983 with the passage of a statute which attempted to $11 \mathrm{mit}$ liability for injuries caused by intoxicated underage motorists. However, comon-law rights are not abridged under the statute. Thus, liability risk for licensees remains broad following the 1982 Chastain decision.

In Texas (Bcore=53.0) two highly publicized dram shop liability cases made their way through the Texas courts in the-early 1930s. In 1987, the Texas supreme Court ruled in the combined cases of El Chico v. Poole and Joleema $v$. Evans, that licensees have a duty to the general public not to serve alcohollc beverages to a person whom the licensee knows or should know is intoxicated. This decision represented a major change in Texas law and was lollowed immediately by legislative action. The statute passed in 1987 allows liability for service to an intoxicated person only when the drinker presents a "clear danger" to himself and others. This statute precludes common-law actions for service to intoxicated adults but does not preclude suits for service to minors under 18. Another statute passed in 1987 has also had a major impact on liability risk. This statute provides immunity for licensees who require their employees to attend state approved "seller training" programs. This statutory immuity from liability will encourage widespread participation in seller training programs even though training is not mandatory.

A summary of findings concerning server liability and legal tradition for each state is shown below:

\section{Bumbry of Findinga, Concerning legal Tradition} for server Llability

\begin{tabular}{ll}
\multicolumn{1}{c}{ State } & Type \\
\hline Arkansas $(8.2)$ & Low \\
Delaware $(17.7)$ & Low \\
Kansas $(8.2)$ & Low \\
Maryland $(1.2)$ & Low \\
Nevada $(8.2)$ & High \\
Indiana $(70.3)$ &
\end{tabular}

Pennsylvania $(70.0) \quad$ High

North Carolina (55.0) Change 1983 state case and statute
Result

Case law precludes liability Case law precludes liability Case law precludes liability case law precludes liability case law precludes liability

Common-law liability allowed despite statute Massachusetts $(60.3)$ High Common-law liability allowed

Common-law ilability allowed despite statute south Carolina $(65.0)$ High Common-law liability allowed 

training

8erver Ilablilty Ineurance--The project investigaied the availability of data on liablitty insurance of alcohol beverage serving establishments. Two studies were undertaken. Cne was an analysis of data from a survey of all state insurance commissioners and insurance trade associations by the Responsible Hospitality Institute to determine what data were available on insurance sold within the state and on suits and final payments made in liability suits. A secord result of research focused on a review of existing reference materials and documents concerning server liability insurance.

The results of the surveys are informative but, in our judgement, ilmited due to (a) low response rates and (b) iack of available data on liability insurance rates and liablitty payments. Nevertheless, some general patterns emerge. Often the most prevalent source of liability insurance in a state is a high-risk insurance company or "surplus line" or "excess line" carriers. Such sompanies, which specialize in providing insurance under situations of high or uncertain risk at high premiums, are often not required to be Iicensed in the states in which they do business. They likely do not belong to traditional insurance associations. Since they may not be licensed, state insurance commissioners often do not collect data regarding their activities. There is no national (across state) source of data, and since states vary in their reporting requirements for insurance carriers, there is often no government monitoring of insurance carriers providing liability insurance to licensed beverage establishments.

Based on review of available insurance data and jocuments from published public sources, the project found that in the absence of barriers to entry or collusion, the insurance market for liability coverage appears to be reasonable competitive. There exists assigned risk or limited liability pools (insurers of last resort) which enable high risk retailers to be subsidized by those of low risk. These pools can dilute incentives to adopt preventive serving practices by those retailers who service practices may be most likely to produce serious injuries or deaths for patrons after leaving their establishment.

Both the analysis of survey results and published data suggests that insurance rates for server liability could be based on relative risk of claims and level of liability payments. In the absence of such information, premium rates do not necessarily reflect actual relative risk but a type of assigned risk which appears to be based on an estimate of risk not based on actual experience. Further, even in states with relatively low liability, such as California, insurance premiums has increased dramatically.

A few insurance companies are beginning to offer discounts for evidence of serving practices and formal server training. They do not conduct a risk assessment of the licensee, but rather only requize evidence of training. 
Llablifty states--In order to determine the amount of public attention or publicity given to server liability in various states, a contenti analysis of newspaperis and trade journals in each case study state was undertaken. This analysis which used available issues from each state over 1984-1988 providud counts of average annual number of articles and column Inches devioted to such server liability and related matters in each state over the eive year study window.

Results of local newgpaper and beverage trade journal content analyses showed that high liablilty states do give more public attention to liablilty losues than low liability states. Both public newspapers and the specialized journals within states with high server liability give more space more erequently to such topics than in states with low server liability.

High liability states (Massachusetts and Pennsylvania) have the most publicity about server liability. The general public and licensed establishments are exposed to more information about server liability in these two states (both via the trade journals and local newspapers) than in any other states within the high liability group. However, within this high liabllity group the most trade journal coverage for server liability is in south carolina which gave no attention to liability in the local newspapers. This suggests inconsistency between the editorial policy of the trade journals and the concern of the local newspapers within a high liability state. Indiana which is the rated as the highest liability state in the country has relatively few articles in both the trade journal and the local newspapers.

Even if the low llablility state group has on-the-average lower attention to server liability within both trade journals and newspapers, this difference is not consistent across all states. For example, the Arkansas beverage trade journal has given a great deal more attention to liability than any other low liability case state, even more than any high liability state beverage trade journal other than South carolina: On the other hand, there was no coverage of server liability by the local newspapers in Arkansas. Kansas and Maryland both have higher newspaper coverage of server liability than Indiana or South Carolina, both high liability states.

\section{In Summary:}

--States with high potential server liability have more publicity about such liability in both local newspapers and beverage trade journals serving thesie states than in states with low potential server liability.

-- -atics within each Low and high liability group have considerable variability in the level of publicity overall and between newspaper ind trade journal coverage within the state. This means that each high 1: abijity state does not always have a level of publicity higher than -ucn low ilability state.

- irade journals give more coverage on the average than local newspapers about server liability. There are three low liability states (Arkansas, Delaware, and Nevada) and one high liability state (تnuth Carolina) with no newspaper coverage at all over the sive years smidis As nvidenced by South Carolina (high state) and Arkansas 
(low state) the trade journals are more concerned about liability than the popular press.

--Both high and low liability states have some publicity about server liability. The lowest attention to liability occurs in Nevada (iow state) but even in this state there is even a small amount of trade fournal coverage. In fact, as a low liability state, there have been liability suits in this state as evidenced by the cases reaching the state appeliate courts.

--Indiana as the state judged in the legal analysis to have the highest potential server liability has rather moderate to low coverage in both journals and newspapers. One might conclude that Indiana was a low liablitty state based on publicity alone.

- If the coverage that newspapers and trade journals give to the server liability reflects the level of concern about liability witnin the state, the higher the potential liability the greater the news coverage and publicity given to such matters.

--If publicity and news coverage reflects exposure (and potential awareness) to level of liability within a state, then licensed established within high liability states will have more awareness.

Mlcohol Beverage Berver Behavlor, Perception, f Training, and Practices

One of the impurtant goals of this project was to learn whether differences in dram shop liability were associated with differences in serving practices and management policies. Since primary data collection was precluded under the contractual terms of this project, data from high and low liablilty states contained within a survey undertaken by Top Shelf Magazine (a national trade magazine for establishments with licenses for alcohol beverage service) and the Responsible Hospitality Institute were analyzed. The survey data provided to the project by Top Shelf Magazine involved three mailings to 7200 randomly-selected licenses across the survey states. The final response rate was $11.7 \%$ overall which reflected a $10.3 \%$ rate from low liability states and $13.5 \%$ from high liability states.

There is a high degree of similarity between the respondents from the two types of liability states. The high liability states respondents are slightly more from bars and nightclubs than low liability (4lo to 34t), more independently owned businesses ( $95 \%$ vs $89 \%$ ), and have been in business a bit longer.

The questionnaire was designed to cover the following topics: awareness of the risk of liquor liability lawsuits with the respondent's state, liability insurance coverage and availability, server training, serving practices, and descriptive information about the business establishment itself.

An equal percentage of restaurants with beverage licenses and of bars/nightclubs responded (approximate 408 each). The majority of responding cutlets were independently owned and most employ fewer than 10 service staff. Beer is the single beverage sold most often.

In general, servers/managers from high liabilit.y states are more aware 
that they can be sued, more aware of suits within their state, and: viow the liability climate in their state as more unfavorable or hostlie than those from low llablilty states. Respondents from high liability states are alightly more ilkely to have liability insurance (49: to 35\%), but raasons for not obtaining insurance are quite different. of those who don't have invurance, many more (37\%) low liability state respondants cite "I do not need" as do high liability (28).

In terms of practices there are little differences between low and high liability states in providing training for their servers and in checking identiflcations for underage patrons. Respondents are identical in citing the use of large drink sizes for service (78\%).

The most significant differences occur in reports of drink refusal and in providing price incentives. For example, $50 \%$ of high liability respondents report refusing drinks to intoxicated customers more than once or twice a month compared to $34 t$ for low liability, and only 98 of high liability state respondents report providing low price incentives (such as happy hours) compared to $30 \%$ of low liability state respondents. While Massachusetts specifically bans happy hours, a statistically signiflcant difference remains when this state is dropped in the comparison.

While the relatively low response rates to this survey suggests caution in interpreting these findings, the observed differences between low and high states are not unexpected. The data do appear to be statistically robust and are consistent with our original model shown later in Figure 3.

\section{In Summary:}

- Alcohol beverage establishments from high liability states are more aware of their liability than their counterparts in low liability states. Thus their perceptions match the independent rating of states by the legal experts.

--High liability state respondents tend to obtain liability insurance more often and few believe they do not need such insurance, even if they fail to purchase $1 t$.

--Liability does not appear to stimulate formal training or underage checking more often. jstablishments in both types of states conduct training and check IDs equally often.

--Liability does reduce low-price promotions and increase refusals of service to intoxicated patrons.

Effect of Liability on Alcohol Involved rraffic Problems -- Both North Carolina and Texas were examined in an effort to determine if a sudden change in liability resulted in a decline in alcohol involved traffic srashes. Cross-sectional analyses of publicity and server perceptions and behavior provide inportant information about existing differences between states with different liability climates. They do not provide information about the potential impact of liability in reducing traffic problems involving drinking and driving. Such a determination 
requires a longitudinal design in which one is able to examine changes in the dependent variable, alcohol-involved traffic crashes, following a significant change in the independent variables e.g., liability exposure and awareness. Such a design was applied to both case study etates.

North Carolina had relatively low llability before 1980 as there had been little or no court activity around such liability and there was no legislation addressing the subject. However, $\bar{c}$ number of significant events occurred to change the situation. From 1979 through 1982 liability suits were entered in North Carolina courts culminating in a N.C. Appellate Court decision which upheld an earlier decision for the plaintiff that serving alcohol to and allowing an obviously intoxicated patron to drive away (who later crashes) was basis for liability. In addition, as a part of the North Carolina "Safe Roads Act", a major drinking and driving legislation which became effective in October, 1983, one of the specific provisions of the law was to establish llability for negligent alcohol sales to underage persons when injuries are proximately caused by this underage person.

In December, 1983, the state Court of Appeals upheld liability of a package store for selling beer to minor who subsequently were involved in traffic crashes. In April, 1985, this same court held that there was contributory negligence of a intoxicated person in consuming sufficient alcohol to be impaired which could be used as a defense to bar negligence liability of a licensee.

Patterns of indicators of alcohol-involved traffic crashes including total fatal crashes and single-vehicle nighttime (between $8 \mathrm{pm}$ and 4 am) crashes were examined for the period January 1980 through December 1988. In addition, content analysis of major newspapers and of television stations news broadcasts were undertaken.

A visual examination of the time series plot of single-vehicle nighttime crashes for changes associated with two significant liability suits (December 1982 and June 1983) and the December 1983 Court of Appeals decision for the plaintiff suggests an associated decline. However, the project was unable to undertake a time-series statistical analysis of this or any other variable due to the fact that these important court actions were so close in time to the effective date of the major drinking and driving legislation in the state. This legislation and the concurrent publicity about drinking and driving make isolation of the potential effect of a change in dram shop liability impossible.

Some general observations which can be made from examination of the data from North Carolina include:

- While beer outlet availability remained relatively constant over the period 1980-1988, spirits availability increased, primarily due to iicenses for on premise sales of spirits.

--Independent evaluations of the state legislation to reduce drunk driving inciuding the establishment of server liability for underage service by steward (1985) and Lacey (1987) concluded no impact of the law. However, it would be difficult to separate out the effect of the law from the server liability changes brought about by judicial 
activity independent of the law itself.

--Media coverage of both drinking and driving (concurrent with the drinking and driving legislation) and server liability appears to be highly correlated with observed changes in the number of alcoholinvolved traffic crashes in North Carolina. However, this association was not tested statisticaliy.

Texas, l1ke North Carolina, also experienced a sudden change in liability exposure as a result of key liability suits. Before 1983, there was no court or leglslative precedent for server liability. However, two important liablilty caces were filed against licensed establishments in 1983 and 1984 resulted in considerable public attention to potential liability. Content analysis of daily newspapers in the atate from 1978 through 1988 showed that prior to 1983 there was no publicity about server liability. See Figure 1 . In addition, during 1983, the major state trade newspapers, Texas Beverage Joumal, carrled a number of storles with attending large headines concerning server liability suits.

A Box-Jenkins time-beries analysis was conducted on injury-producing monthly single-vehille nighttime crashes in Texas from 1978 through 1988. Infury producing crashes are those $n$ which at least one vehicle occupant was killed or received an incapacitating or

non-incapacitating injury, as reported by the police officer at the scene of the crash. The effects of several other factors expected to potentially impact injury rates in Texas, were controlled in the statistical analysis e.g., national crash patterns, major Texas drinking and driving legislation in January, 1984 ; mandatory safety belt legislation in December, 1985; and increases in the minimum drinking age from 19 to 21 in September, 1986. See Figure 2.

The final time-serias model parameter estimates revealed significant reductions in the ireguency of single-vehicle nighttime injury traffic crashes following the January, 1983, and the November, 1984, filings of major server liablitity court cases. Crashes decreased $6.5 \%$ immediately after the 1983 case was filed and decreased an additional $5.3 \%$ after the 1984 case was filed. No statistically significant change in crashes was found associated with the January, 1984, Impaired Driving Legislation which occurred between these two cases.

These decreases represent net effects associated with the court cases and associated publicity, after controlling for broader crash trends reflected in data from other states, and controlling for the effects of other major policy changes in Texas in the 1980s, such as raising the legal drinking age, strengthened DUI laws, and requiring safety belt use.

Effects of the lawsults were found at the time they were originally filed, not when appeals courts issued their decisions three to four years later. Presumably this was due to a sudden increase in publicity concerning liability that increased the level of awareness and concern of owners and managers of alcohol outlets. Furthermore, there is evidence that the filing of the 1983 and 1984 cases dramatically i.jcreased the levels of concern among alcohol retailers. The later Appeals court and supreme court decisions simply upheld 
FIGURE 1

Texas Newspaper Coverage of

Server Liability -- 1978-1988

\section{Articles}

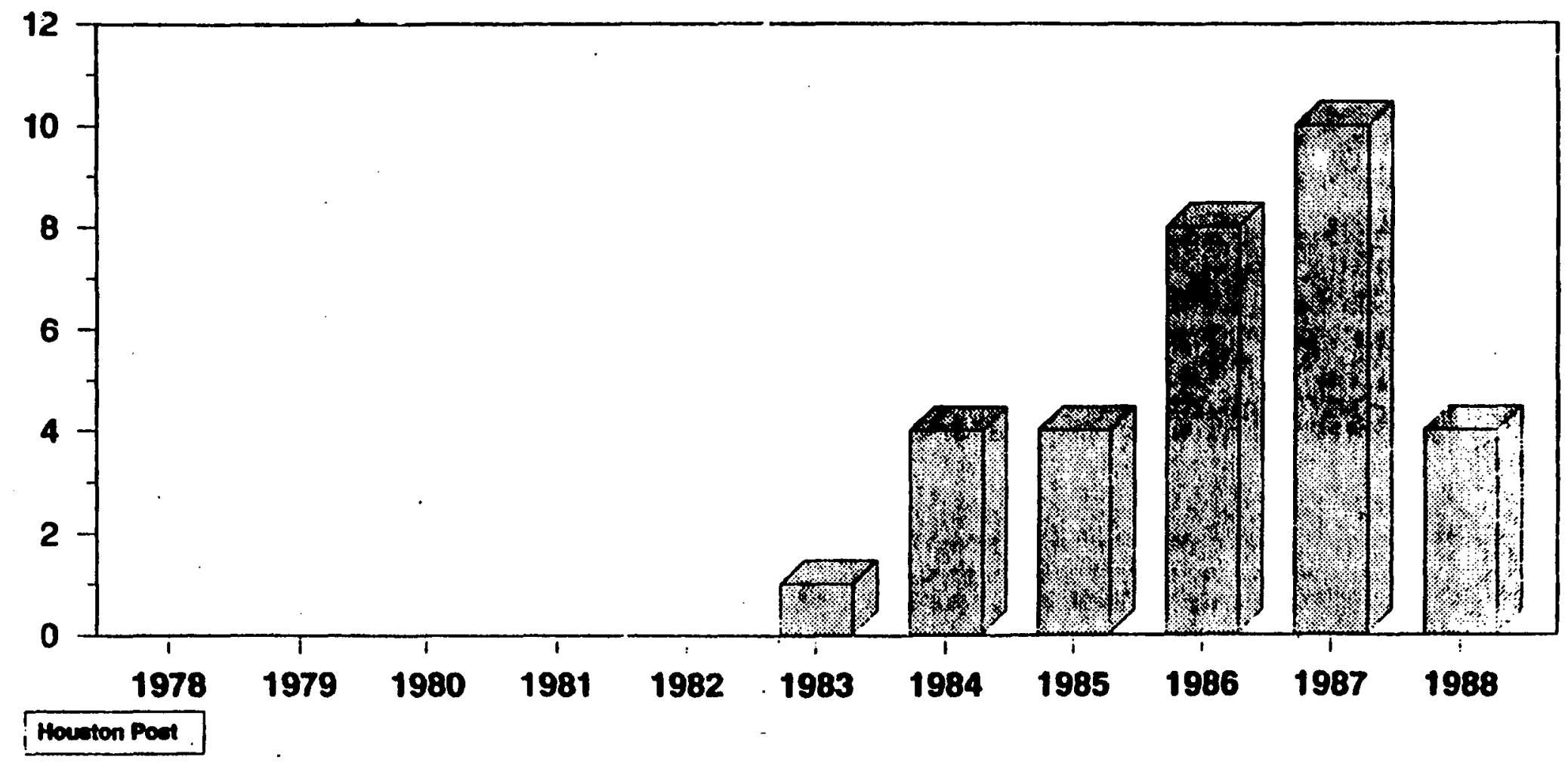




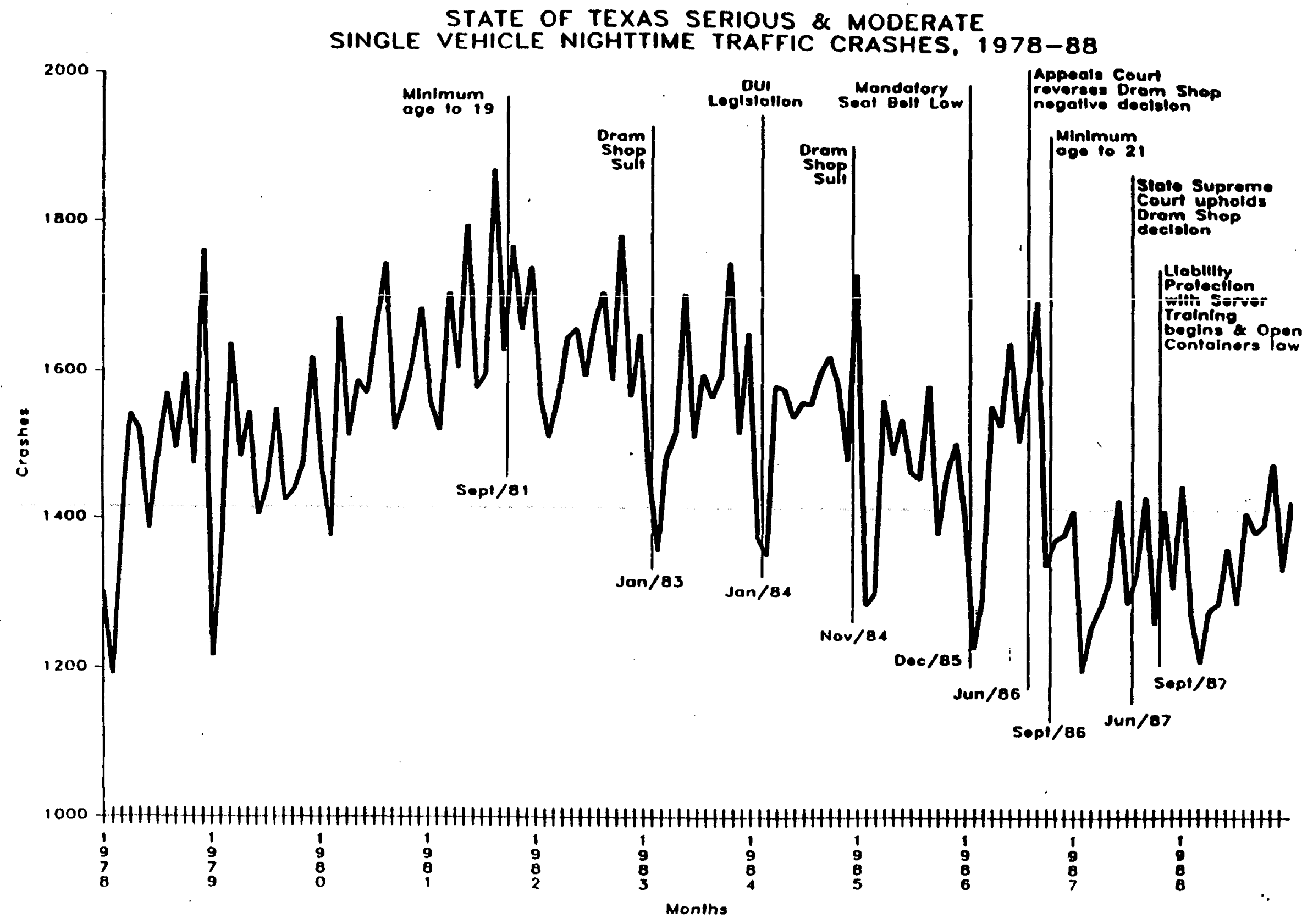


1dability that retallers perceivad baginning at the time the suits were liled.

In addition to abrupt permanent intervention models for the dram shop llability suits, we examined alternative possible forms of the intervention effects. Intervention models tested included a sudden but temporary effect that gradually decayed, and a gradual permanent effect. The sudden temporary effect may obtain if the effect is solely due to publicity, with the effect dissipating as media coverage faded. The gradual permanent effect may obtain if awareness of liability and specific serving practices gradually develop and diffuse throughout the population of alcohol outlet owners and managers. None of the alternative models $f i t$ as well as the more parsimonious suiden permanent effect models. As a result, it does not appear that effects of the suits are solely due to publicity, which inevitably decays over time. It also appears that the role of the media (both general population mass media and speciallzed publications targeted at alcohol retailers) in rapidly disseminating information on these cases supersedes a more gradual diffusion process.

c. The Firal conceptual Model of pram Shop Liability, server Behavior, and Alcohol-Involved Traffic Problems.

This project provided information about a number of factors relating to server liability and its potential impact on reduction of alcoholinvolved traffic problems. These results have both confirmed the importance of specific factors and their relationships.

A conceptual model is shown in Figure 3. This project confirmed the importance of both judicial activity and legislation in defining the nature and extent of server liability in each state, i.e., DRAM SHOP IIABIIITY. The full extent of the impact of GENERAI TORT LIABIIITY in a state on the specific server liability of licensed establishments is difficult to determine across all states. Restrictions on liability imposed by changes in tort liability can have important effects on DRAM SHOP LIABILITY.

A few states heve statutes which either require the training of servers (Oregon) or provide for server training as a potential defense or protection against liability (Texas), i.e., STATE STATUTES ON SERVER IRAINING. The potential preventative effect of IIABILITY INSURANCE has not been fully explored by the insurance industry. There is no empirical basis for currently determining the actual extent of liability exposure. As a result, premiums are established more to protect insurance carriers against the highest estimated risk rather than actual risk.

Based upon results from the survey of licensees from high and low liability states and the time-series analysis of Texas, we conclude that liability exposure does influence the SERVER PRACTICES of i icensed establishments. These practices appear to be related to the OWNER/MANAGER PERCEPTIONS OF IIABILITY RISK which are associated with actual liability. In general, high liability states have more LIABIIITY PUBLICITY than low liability states and owner/managers report correspondingly greater awareness and concern.

Licensed establishments from high liability states are more likel' 
Figure 3

C and H Reseuroe Assoefotes, be. Mereh 24, 1990

\section{Conceptual Model of Dram Shop Liability, Server Practices, and Alcohol-Involved Traffic Problems}

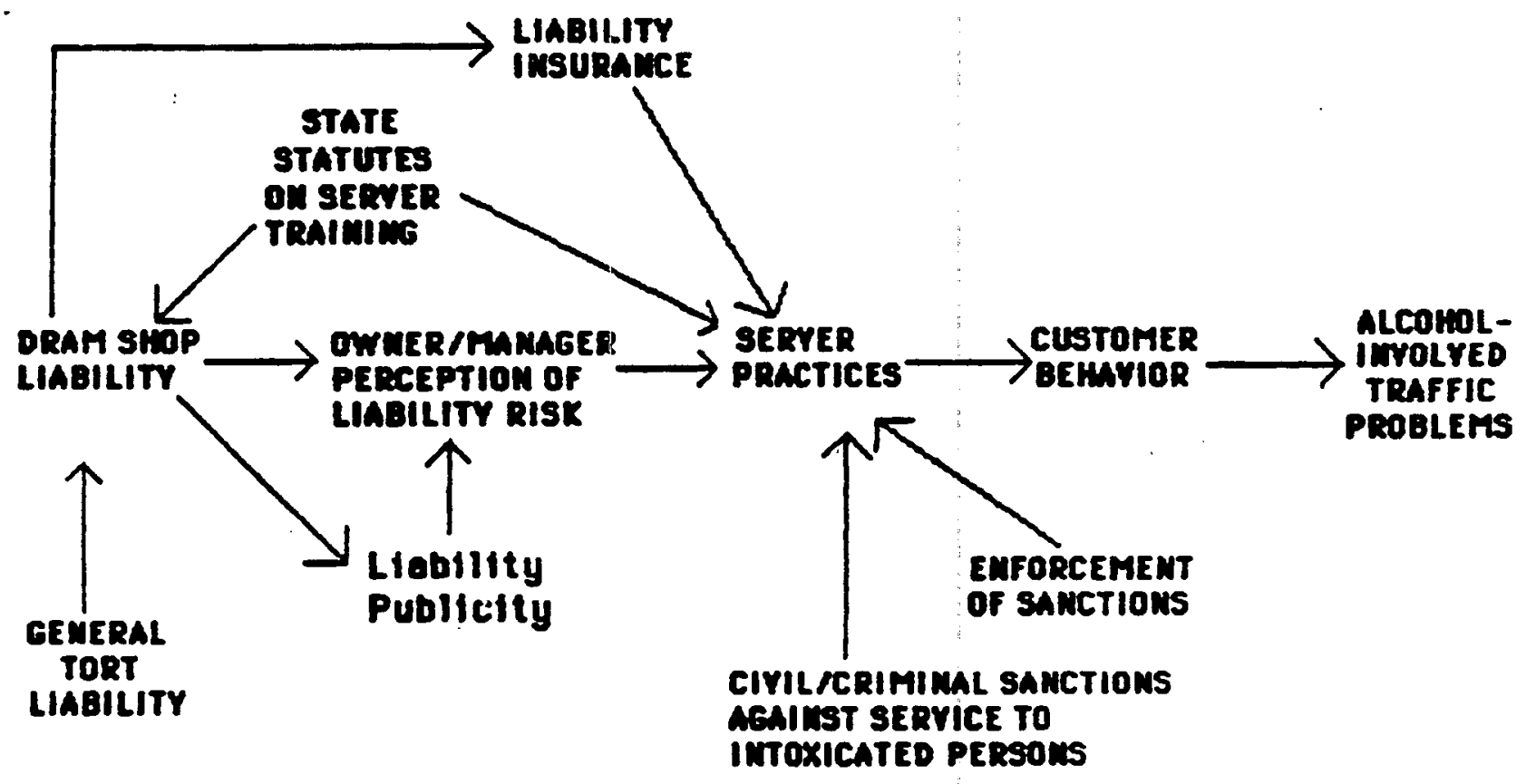


to purchase liability insurance or know that they should have insurance if they do not purchase it. Establishments from high liablifty states are much more likely not to have price promotions and are more likely to cut off intoxicated patrons than establishments from low liability states. These are specific behaviors which are related to liabllity and associated publicity and perceptions. Such practices as formal training of servers and checking identifications of possible underage patrons are not differentially stimulated by liability according to the eurvey results. These practices occur as often in high as in low liabliity states.

The specific effects of state SANCTIONS AGAINST SERVICE TO INTOXICATED PERSONS and ENFORCEMENT OF SANCTIONS were not investigated by this project. Most states have these sanctions. Only Alabama, Florida and Nevada do not have either civil or criminal sanctions against service to intoxicated persons. In most states such laws are enforced by the Alcohol Beverage Control authority and is most often the basis for loss of license and/or fines. States which are more restrictive about the availability of alcohol have more enforcement of ABC laws including underage service (Prevention Research Center, 1990). Enforcement is not necessarily associated with the level of server liability. This may explain why there are no differences in formal server training and checking IDs between high and low liability states.

This project was not able to directly examine the impact of changes in SERVER PRACTICES and CUSTOMER BEHAVIOR. However, the research of Saltz (1985, 1987), McKnight (1987), Gliksman and single (1988), and Russ and Geller (1987), and Geller and Delphos 1987 demonstrate that changes in serving practices do result in reductions in the number of intoxicated persons leaving establishments. Such research supports a conclusion that changes in SERVER BEHAVIOR can produce differences in the Blood Alcohol Lovel (BAL) of patrons leaving licensed establishments and thus the subsequent risk of becoming involved in a traffic crash.

A potential relationship between SERVER IIABILITY and a reduction in Alcohol-involved TRAFFIC PROBLEMS was demonstrated in this project through the time-series analysis of single-vehicle nighttime injury producing crashes in Texas. This finding strengths the empirical association between changes in liability, associated publicity, server behavior, customer levels of alcohol impairment, and subseguent traffic crashes involving alcohol.

\section{Conclusions and Recommendations}

This section will summarize the overall conclusions drawn by the research staff from project findings and provide recommendations which have implications for policy concerning server liability and efforts to izaduce alcohol-involved traffic crashes. Recommendations for future research are also provided.

Existing state statutes which address server liability (thus establishing a legislative basis for such liability) most often impose restrictions or boundaries on liability which actually limits liability. The high liability states are those where the courts have established liability through judicial decisions not through 
logislative action.

Two hlgh llability etates, Indiana and Pennsylvania, passed statutes about liablilty as a result of public concern. In the lowest liability states, the courts have refused to recognize a common-law basis for liability in the absence of any state legislative action. In general, where there is legislatively defined liability it is in response to Judicial action.

Legislative restrictions tend to reduce the incentives for retailers to engage in safe practices in serving alcohol. In addition, these restrictions often have the effect of (a) setting limits or caps on possible liability payments, (b) eliminating joint and several liability which restricts the ability of the injured party to sue others such as licensed establishments following a traffic crash, (c) establishing stricter liability standards which can reduce the ability of injured parties to enter suits, and (d) providing statutory evidentiary standards which can reduce the information used to support a case of liabllity.

Therefore, a conclusion of this project is that most current statutory responses to dram shop liability do not necessarily contribute to the prevention of alcohol-involved traffic crashes. This is based on two points. First, many state statutes tend to establish boundaries and limits on liability which can be viewed by licensed establishments as reducing actual liability exposure and thus reduce the incentive to alter unsafe strving practices. Second, they rarely provide positive Incentives for licensed establishments to engage in preventative behaviors or practices.

We believe that statutes which provide incentives to retailers to seek such activities as server training and modifications of serving policy and practices will have a greater potential to reduce the risk (1ikelihood) that patrons will be served to intoxication, that intoxicated patrons will leave a licensed establishment, and that underage persons will be served. One example of such legislation is the Model Dram Shop Act developed under a grant from the National Institute on Alcohol Abuse and Alcoholism (Prevention Research Group, 1985). At least one state, Rhode Island, has adopted this act.

Without anything else to provide incentives for responsible serving practices, the higher the server liablitty the better (for example, the case of Texas). While the "stick" (high liability) has been shown to be effective, the project concludes that incentives as "carrots". are more desirable and have the greatest potential to reduce drinking and driving in the long run.

Pure high liability is not necessarily in itself most preventative. Even though a change in ilability may, produce a change in server behavior, as shown in Texas, legislative incentives may in the long run hold the most potential for preventative effects. This project has concluded that maximum liability exposure alone does not necessarily lead to incentives or server behavior to reduce alcohol involvement among arivers.

Insurance for server liability is a significant ingredient in evaluating server liability impact. However, the lack of infomation about actual risk of liability exposure either jncurred bil a specific 
1leensed establishment or types of establishments within a state means that there is currently no emplrical basis to establish risk and determine appropriate insurance promiums.

This project has concluded that it may not be desirable to have excess ilne companies writing insurance for server liability. This conclusion is on two grounds: (1) pramiums are not based on actual exposure in existing law and actual case activity, and (2) there are no incentives provided by ouch companies for retailers to engage in preventative practices such as server training or reduce promotions which can increase the level of patron intoxication.

This project found that it was difflcult to locate and obtain beverage trade journals, newsletters, and newspapers. We found it notable that these valuable sources of data on the types and amount of news and aditorial content which owners, managers, and servers are exposed to are not readily available. As the Ilcense beverage retail industry is orientated around state and local issues, there is no national source of such valuable data across states. Even at the state level, industry newsletters are typlcally not retained and are not available to the scientific community.

This project is the first to find an association between drinking and driving and server llability. While the effects on single-vehicle nighttime injury traffic crashes in Texas following significant changes in liabliity and the attending publicity were modest, they were statisticaliy significant amidst a number of other efforts to reduce traffic crashes and injuries.

This project concludes, based upon both the legal and empirical research findings of this project, that dram shop laws can be preventative. Using different sources of information which provided further confirmation of single findings, we found that retail establishments do respond to changes in liability and to the existence of high liability. This was shown in both the server survey and in the analysis of changes in traffic crashes in Texas. It can be concluded that such laws stimulate responsible alcohol serving practices that the preventative potential to reduce alcohol impaired driving is enhanced.

Specific recommendations are:

-clarify the specific impact of existing (and future restrictions) on server liability, court and legislative action. Future legislation should clarify negligence and recklessness as standards of liability. The doctrine of joint and several liability should be reviewed to ensure falrness to incidental defendents while taking plaintiff's conduct and damages in account. Legal reform measures should be based in general negligence law and shall be clearly and carefully drafted.

-Future legislative, judicial, and state government actions should coordinate the reform of dram shop liability with general negligence laws and Alcoholic Beverage Control laws, and regulations which can affect the serving practices of licensed establishments.

--Information on liquor liability insurance can and should be collected. Without more active data collection efforts by state 
Insurance comissicns on premiums charged for server liablilty Insurance and on actual liablilty payments and exposure, research on this tople $1 \mathrm{~s} 11 \mathrm{mit}$ ed and insurance premiums can not be based on actual risk exposure. Active mandated data collection in a state (for example in the case of the state of kichigan) can enhance competition within the market and lower insurance rates. By stimulating compotition and reporting rates and 1085 ratios, state regulator agencles ald competitors to effectively enter the market. Insurance costs can then be adfusted to reflect actual relative risk more accurately.

- states need to create liablilty pools which can make lower cost Insurance avaliable to licensed establishments and provide positive incentives for establishments to engage in safer serving practices.

- It is recommended that either the beverage serving industry and/or schools for hotel and restaurant management training be encouraged to develop and maintain central depositories for publications designed for establishments 11censed to serve alcohol. Without such centralized collection of materials and data, future research on policies and historical trends of direct relevance to the reduction of drinking and driving will be loot or not easily available to the industry or researchers.

- Further research 1 needed to confirm the rather modest reductions in alcohol-involved traffic crashes associated with server liability in a single state. We will have more confidence in the robustness of these findings as similar research is replicated in other states and in different time periods.

- Future research is needed to document the potertial changes in customer behavior resulting from specific changes in serving practices and behavior directly in response to changes in liability. The existing evidence on the impact of such changes on customer behavior comes from evaluations of server training not evaluations of changes in server liability. 


\section{BIBLIOGRAPHY}

Geller, E.S., Russ, N.W., Delphos, W.A.: "Does server intervention make a difference?" Alcohol Bnalth Res World 11:64-69, 1987.

Gliksman, I. and Single, E.: A fleld evaluation of a server intervention program: "Accomodating reality." Paper presented at the canadian Byaluation Sochty Meetings, Montreal, Canada, May, 1988 .

Iacey, John. 1987. "Safe Roads Acts Updates." Prepared for North Carolina Medical Society, Traffic Safety Committee. UNC Highway Safety Research Center, Chapel Hill, NC, April 12.

Mcknight, A.J.: "Development and Fleld Test of a Responsible Alcohol Service Program. Volume I: Research Findings." National Highway Traffic Safety Administration, U.S. Department of Transportation, Report No. DOT HS $807221,1987$.

Prevention Research Center, "Report of state Alcoholic Beverage Control Authorities and Activities," Berkeley, CA. Unpublished Report. 1990.

Saltz, R. F. Server Intervention: Conceptual overviews and current developments. "Alcohol, Drugs and Driving": Abstracts and Reviews 1:1-14, 1985.

Saltz, R.F. "Evaluating server intervention: A prelimirary repozt," paper presented at American Public Health Associatior annual meetings, November 1985.

Saltz, R.F. "The Role of Bars and Restaurants in Preventing Alcohol-impaired Driving: An Evaluation of Server Intervention." Eyaluation and the Health Professions. 10(1): 5-27. 1987.

Stewart, J. Richard. "Estimation of the Effects of Changes in Drinking and Driving Laws on Alcohol Related Automobile Crashes." Chapel Hill, NC: UNC Highway Safety Research Center, HSRC-A113, 1985, p.10. 